\title{
QUARTERLY ANALYSIS: The Progress of Monetary, Banking and Payment System Quarter 3, 2009
}

\author{
Quarterly Report Team, Bank Indonesia
}

The development of global economy, which tends to recover, has provided good impacts to the domestic economy. Indonesia's economy has potentials to grow better than the early estimate, both for the year of 2009 and for the year of 2010.In 2009, Indonesia's economy was estimated to grow 4.0-4.5\%, or higher than the previous estimate, which was 3.5-4.0\%. Meanwhile, for 2010, the economic growth is estimated to reach $5.0-5.5 \%$.

Economic growth taking place in the global economy continuously indicates to be stronger and more evenly spread in many countries. Such recovery is mostly seen in emerging market countries in Asia, particularly China. Meanwhile, in advanced countries, economic contraction starts to be slower. From various global macroeconomic indicators, it is seen that optimism at global economic recovery is getting stronger. Progresses of grocery sales, capacity utilization, and product index start to increase, both in advanced countries and emerging market countries. Even though there is recovery, some risk factors still hang over it. Risk on high level of unemployment in advanced countries and emerging market countries becomes an obstacle to further improve the global economic performance.

Recovery occurred in the world's economy is also reflected by better development of global financial market. Throughout Quarter III-2009, risk levels of advanced and developing countries started to be better. This could be seen from the development of risk indicators or Currency Default Swap (CDS) that continuously decreased. In Quarter III-2009, the global share market was still in the increasing trend, even though it experienced price correction. In the real sector, optimism to the economic recovery and the weakening of US dollars encouraged the increase of international commodities prices. However, such price increase did not give significant pressure to the general price increase. Inflations in advanced and emerging markets countries were still low; some countries even experienced deflation along with the unrecovered consumption performance. 
From the domestic side, Indonesia's economy showed better development in line with the better condition of global economy. The GDP growth in Quarter III-2009 was estimated to reach $4.2 \%$, higher than the early estimate of 3.9\%. From the demand side, the consumption performance increased, supported by the increased export revenues, stronger confidence of customers, and seasonal factors of welcoming the 'Idul Fithri. Investment performance was estimated a little bit better, even though it would grow low. From the external side, the export growth was estimated higher, in accordance with the better economic condition of trading partner countries as well as the increased prices of global commodities. Meanwhile, the import growth was estimated still minimum. The manufacturing and trading industries, hotels, and restaurants grew better in Quarter III-2009 along with the 'Idul-Fithri celebration.

Such better Indonesia's economic growth was also confirmed'from the'assessment result of regional economy carried out by the Bank of Indonesia. In general, regional economy still reflected that the strong consumption and export were in line with the increased demand of primary products from China, India, and South Korea as well as the increased investment activities in all areas. The increased export from Sumatera and Kali-Sulampua (Kalimantan-SulawesiMaluku-Papua) mainly came from the rubber, nickel, coal, and CPO industries. The growth sources of Jakarta were in the form of manufacturing industry result commodities. Meanwhile, from the supply side, the economic growth of Jakarta was mostly supported by the better performance of industrial, trading, hotel and restaurant, and financial sectors. In Jabalnustra (Java-Bali-Nusa Tenggara) areas, the economic growth was sponsored by agricultural, food vegetation, and trading sectors, whereas in Sumatera and Kali-Sulampua, it was triggered by mining sector and plantation sub sector.

The increase of regional economic growth was also supported by the realization of regional government budgets (APBD) that commonly started to increase in Quarter III-2009. In addition, earthquakes occurred in West Sumatera was predicted would influence the economic growth of West Sumatera. Superior products such as agricultural, trading, hotel and restaurant, transportation, and communication, which all this time has been main growth source in West Sumatera were predicted hit by such earthquakes. However, compared to other region, the economics of West Sumatera against the national growth was relative low, which was $1.7 \%$ of the total national economy.

The trend of inflation decrease during Quarter III-2009 continuously decreased up to $2.83 \%$ (yoy). Such decrease was related to the lower inflation expectation, stronger rupiah exchange rate, and low increase of global commodity price. On the other hand, the demand side pressure was still low, even though there were indications it started to increase. From the non-fundamental sector, during Quarter III-2009, the limited Government intervention in price 
and the excess food supply reduced pressures to the price. The increase of toll road prices on 28 September 2009 was predicted to give impacts on inflation by $0.05 \%$ in 2009 .

The better condition of global economy, mainly the trading partner, was potential to give positive impacts to the performance of Indonesia's Balance of Payment in Quarter III-2009. The global economic recovery and better global commodities prices potentially support higher export performance. Meanwhile, the import was estimated still low related to the low investment needs. The on-going current account of Quarter III-2009 potentially recorded a surplus. Meanwhile, in the Capital and Financial Transactions (TMF) side, foreign fund and investment flow still reached a surplus, even though it ever experienced foreign portfolio adjustment in August 2009.

In addition, according to Moody's, the increase of Indonesia's sovereign credit rating from $\mathrm{Ba} 3$ to $\mathrm{Ba} 2$ was estimated could provide positive impacts to the incoming capital flow and financing cost. Besides, as part of coordinated global policy steps, Indonesia as well as the other IMF member countries, received SDR allocation amounting to SDR 1.74 billion or equal to USD 2.7 billion. Within such progress, foreign exchange reserves at the end of September 2009 reached USD 62.3 billion, enough for 6.2 months import and payment of government foreign debts.

Such better Indonesia's Balance of Payment and the positive sentiment of global financial market also encouraged the stability of rupiah exchange rate. Even though rupiah experienced pressures at the end of August 2009, this rate was stronger with a lowered volatility. The strengthening of rupiah was supported by strong fundamental of domestic economy as reflected in the on-going surplus current account, interesting pay off, and better risk perception, which became interesting matters for foreign investors. In addition, the positive sentiment of global economy also encouraged the heavy of foreign capital inflow to Indonesia. Rupiah was still more competitive than other regional currencies. Throughout Quarter III-2009, rupiah got stronger $5.55 \%$ in average to the level of Rp9,973 per USD with lower volatility.

In the financial sector, the various progresses above gave positive impacts to the condition of domestic financial sector. In general, the performance of financial market increased and the monetary policy transmission continuously got better. In the share market, the development of stock exchange during Quarter III-2009 was remarked by the increase of price index. Better domestic fundamental and increased global commodity price were factors that encouraged share purchase, both by significant foreign and domestic investors. In the obligation market, SUN yield decreased in accordance with the low development of BI Rate and the increased interest of foreign investors. However, SUN yield for long-term maturity (over 15 years) still tended to be higher caused by higher risk perception. 
In the banking sector, the condition of national banking was relative stable and the banking response to the monetary policy signal started to be better. From the micro point of view, the condition of national banking was still stable, indicated by maintained high Capital Adequacy Ratio/CAR per August 2009 which reached 17.0\%. Meanwhile, the ratio of Non Performing Loan (NPL) was still under control of less than $5 \%$ within net ratio of less than $2 \%$. The banking was quite liquid, reflected from increased banking saving in the monetary instruments (SBI and FASBI), larger transaction volume in the money market between banks, and decreased interest rate of overnight Money Market between Banks (PUAB) that tended to be lower than the BI Rate. In addition, response of banking interest rate to the monetary policy was still better, mainly on the reserved interest rate. Up to the middle of Quarter III-2009, the credit interest rate decreased in average of 18 bps or higher than the same period in the previous quarter. Related to this, distribution of banking credit from January to August 2009 noted 46.7 trillion of $3.5 \%$ (ytd).

In the future, the prospect of Indonesia's economy in 2009 and 2010 potentially grows better than the early estimate. This is mainly supported by the strong growth of private consumption, export performance that is higher than the previous estimate, as well as the Government stimulus. Such strong performance of private consumption, supported by the high level of customer's confidence, is in line with the inflation and low interest rate as well as the impacts of increased export revenues. Moreover, the improvement of export performance is influenced by the stronger process of global economic recovery and the increase of commodity price, both oil and gas commodities and non-oil and gas commodities. Investment is predicted to grow limitedly, which relates to the low level of production capacity utilization. Government fiscal stimulus is also able to support the performance of domestic economy, reflected from the higher consumption growth and Government investment. From the supply side, the growth of many sectors is predicted to start to grow. This is in line with the increase of both domestic and external demand on tradable sectors. Within such kinds of development, Indonesia's economy in 2009 was estimated to grow 4.0-4.5\%, better than the early estimate of 3.5-4.0\%. Meanwhile, for 2010, the Bank of Indonesia estimates the economic growth may reach 5.0$5.5 \%$. Some risk factors should be concerned for instance come from the uncertainty in the process of world trading recovery, considering that the recovery process in advanced countries, which is supported by fiscal stimulus, is more oriented to the domestic demand and labor intensive sector in advanced countries. In addition there is high tendency on protectionism in some countries after the global crisis. Moreover, risk on the increase of world oil price, triggered by speculation activities, should be aware. 
In 2009 and 2010, the Balance of Payment is estimated to reach much better surplus. Exporting activities were predicted to be better, supported by the process of world economic recovery and the increase of commodity price. In the domestic side, the import was predicted to grow limitedly, concerning that the growing investment activities are still low. Meanwhile, for 2010, the on-going current account is estimated to record a surplus. In addition, capital transaction and financial performances are supported by the more conducive domestic and external conditions against before. Maintained condition of domestic fundamental, better risk perception, and strong interest of investors to the domestic assets are predicted to encourage the inflow of foreign capital to Indonesia, both in the forms of portfolio investment and foreign capital investment.

In the inflation prospect, the trend of inflation decrease in 2009 was predicted to continue but potentially return to the normal pattern in 2010. During 2009, CPI inflation was estimated as targeted of $4.5 \pm 1 \%$. For 2010 , CPI inflation is estimated to go back to the normal pattern of $5 \pm 1 \%$. This relates to the increased domestic economic activities, raised imported inflation that is connected with the increase of commodity price, and inflation expectation. From nonfundamental side, the increase of inflation pressure is predicted coming from the increase of some non-strategic administered prices. Meanwhile, volatile food inflation is estimated will be quite low, in accordance with the fairly maintained supply and distribution of food and energy.

By considering such progresses above, the Meeting of Governors Board of the Bank of Indonesia in 5 October 2009 decided to maintain BI Rate at the level of $6.5 \%$. The meeting concluded that the target $6.5 \%$ is consistent with the achievement of inflation target in 2010 , $5 \% \pm 1 \%$. The present policy stance is also considered to be conducive for the process of economic recovery and banking intermediation. 
this page is intentionally blank 